\title{
Job Satisfaction Factors Influence on Turnover Intention of PT Bank BRI Syariah Employees
}

\author{
Muhamad Rizqan Lutfi Akbar ${ }^{1}$, Fetty Poerwita Sary ${ }^{2}$ \\ \{larizqan@gmail.com¹, f.poerwitasary@gmail.com $\left.{ }^{2}\right\}$ \\ Commercial Banking Division, PT Bank BRI Syariah Tbk., Indonesia ${ }^{1}$, \\ Department of Management, School of Economics and Business, Telkom University, Indonesia ${ }^{2}$
}

\begin{abstract}
This study was conducted to investigate the influence of job satisfaction on the turnover intention of PT Bank BRI Syariah Tbk. employees. Independent variables in this study include work itself (X1), salary (X2), promotion (X3), supervision (X4), and colleagues (X5). On the other hand, the dependent variable is turnover intention $(\mathrm{Y})$. An interview had been done with 100 employees. Then, the results were categorized into five classifications and analyzed using descriptive tests and multiple regression. It was found that the multiple regression is (X2) with significant at alpha 5\% with value (0.009695). The variable selection was also conducted using the Stepwise method. It was found the $\mathrm{p}$-value of the F-test is $(1,473 \times 10-7<0.05)$ where there is at least one independent variable that affects $(\mathrm{Y})$. It was revealed that two variables had a negative and significant influence on turnover intention, which are salary (X2) and promotion (X3).
\end{abstract}

Keywords: BRI Syariah, Job Satisfaction, Payment, Job Promotion, Turnover Intention. 


\section{Introduction}

Human resources have an important part to support company development and the key factor in providing service, innovation, and creativity. The aforementioned aspects could improve company performance and could be an advantage in the competition [1,2]. The importance of human resources for a company is a rationale for a company to be able to properly manage its human resources. One of the efforts in managing human resources is by increasing each of its employees' job satisfaction and decreasing their intention to leave the company.

[3] It is explained that job satisfaction encompasses several aspects that include the satisfaction in doing the job itself, salary satisfaction, satisfaction with promotion, satisfaction with their superior, and satisfaction with their coworkers. It was found that job satisfaction is inversely proportional to the intention of the employees to leave a company as high job satisfaction will lead to the lower turnover intention of employees [4].

The turnover level of BRI Syariah respectively from 2015 - 2018 was $17.95 \%$, $15.55 \%, 15.08 \%$, and $19.25 \%{ }^{1}$. The high percentage of turnover in 2018 was disadvantageous for the company because it would impede the company's performance.

The initial sampling process was conducted to 17 BRI Syariah employees. In this case, the sampling process was taken by considering the employees' job satisfaction towards its variable, which are salary, promotion, supervision, and co-workers. It was found that $58.8 \%$ of the respondents were not satisfied with their salary. Moreover, it was also revealed that $29.4 \%$ of them were not satisfied with their promotion and colleagues.

Table 1. Job Satisfaction Pre-Study Result

\begin{tabular}{ccrrrrr}
\hline No & Variable & VS & \multicolumn{1}{c}{ S } & \multicolumn{1}{c}{ A } & \multicolumn{1}{c}{ DS } & \multicolumn{1}{c}{ VDS } \\
\hline 1 & Work Itself (X1) & $0.0 \%$ & $41.2 \%$ & $29.4 \%$ & $29.4 \%$ & $0.0 \%$ \\
2 & Salary (X2) & $0.0 \%$ & $0.0 \%$ & $11.8 \%$ & $58.8 \%$ & $29.4 \%$ \\
3 & Promotion (X3) & $0.0 \%$ & $5.9 \%$ & $47.1 \%$ & $29.4 \%$ & $17.6 \%$ \\
4 & Supervision (X4) & $0.0 \%$ & $41.2 \%$ & $41.2 \%$ & $11.8 \%$ & $5.9 \%$ \\
5 & Colleagues (X5) & $29.4 \%$ & $47.1 \%$ & $23.5 \%$ & $0.0 \%$ & $0.0 \%$ \\
\hline
\end{tabular}

$$
\begin{array}{ll}
\multicolumn{2}{l}{\text { Explanation: }} \\
\text { VS } & \text { : Very satisfied } \\
\text { S } & \text { : Satisfied } \\
\text { N } & \text { : Average }
\end{array}
$$

${ }^{1}$ BRI Syariah financial report https://ir-brisyariah.com/annual_reports.html 
DS : Dissatisfied

VDS : Very dissatisfied

Based on the description above, a study concerning the relationship between employees' turnover intention and their job satisfaction in BRI Syariah was conducted.

\section{Theory and Research Methodology}

Herzberg's theory [5] regarding job satisfaction, which is also known as the "two-factor theory", exerts that job satisfaction is related to the motivationhygiene factor. According to this theory, a motivator is an intrinsic force that improves job performance, which comes from within an individual. It relates to jobs that offer achievement, recognition, challenge, responsibility, and prospect for progress. On the other hand, hygiene is an extrinsic factor (from outside an individual) that relates to the company's policy, supervision, salary, work relation, and working environment.

According to Handoko [6], job satisfaction is a pleasant or unpleasant emotional state in which the employees consider their employment. Job satisfaction reflects employees' feeling towards their job and everything that have to be encountered in their working environment. In this case, the human resources division has to monitor their job satisfaction, motivation, complaint, and other vital personnel issues.

Schwartz [7] indicates five indicators of job satisfaction, which are salary, promotion, colleagues, supervisor, and work satisfaction. It was also explained that intention is a motive of the desire of an employee to do something while turnover is quitting, changing job, or employee withdrawal from a company that they are currently working for to a different company [8]. Therefore, it can be explained that turnover intention is the motivation of employees to quit their current job and to find a new one for a certain reason.

Turnover refers to a situation where an individual is resigning his or her membership in an organization. In this case, Faslah [9] describes the cost or the loss of a turnover as follows: 1) direct cost for the recruitment process; 2) indirect cost for new employees training, and 3) productivity loss caused by the new employee training process.

The high employee turnover can be observed by investigating the employee motivation to leave the company or organization that they are currently working for [10]. According several studies[11][12][8], employee turnover intention can be observed by looking at five indicators, which are the decrease 
of attendance rate, laziness, violation of work rules, tendency to oppose or protesting to superior, and unusual negative behaviors.

Based on Albatat et al. [13], it was revealed that to measure turnover intention, several aspects can be measure, which the motivation to leave, looking for an alternative, and quitting. Based on the aforementioned theory, this study conducted an observation using the framework in Figure 1:

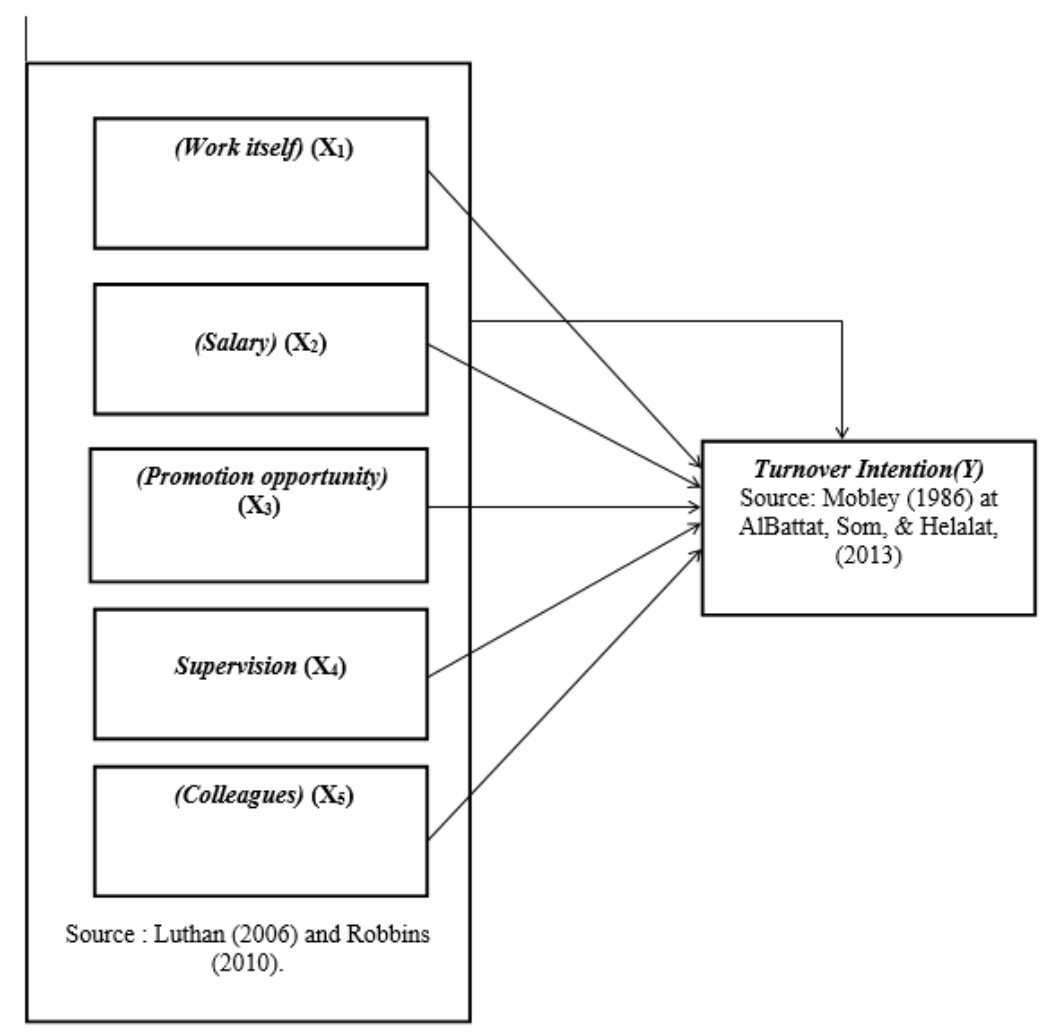

Fig. 1. The architecture of a typical wireless sensor node

This study is using a qualitative approach. Sugiyono [14] explained that qualitative is a research method based on positivism philosophy. It is employed to study a certain population or sample, data collection using research instrument, quantitative analysis, and statistic to test the predetermined hypothesis. Moreover, qualitative method could also describe the phenomena that relate to the studied variables, which are, in this study, job satisfaction and turnover intention of the BRI Syariah employees.

In addition to qualitative approach, this study also employed probability sampling. It is a sampling technique that could provide a similar chance to all 
of the population members to be selected as a sample [14]. In this case, 100 employees of the BRI Syariah were selected as samples. In addition, to collect the data, the Likert scale questionnaire method was employed. This study used multiple regression descriptive analysis by using SPSS version 23.0 to support it. Regression analysis is conducted to predict or to reveal the influence of the independent variable on the dependent variable [14]. Partial significance tests (t-test) and simultaneous significance tests (f-test) were used to test the hypothesis.

Table 2. Interpretation of the score indicator of the research variable

\begin{tabular}{ccc}
\hline No & Score & Interpretation \\
\hline 1 & $1-1.8$ & Very dissatisfied \\
2 & $>1.8-2.6$ & Dissatisfied \\
3 & $>2.6-3.4$ & Average \\
4 & $>3.4-4.2$ & Satisfied \\
5 & $>4.2-5.0$ & Very satisfied \\
\hline (Sources: Sudjana $[15]$ )
\end{tabular}

\section{Result and Discussion}

Descriptive analysis was conducted to reveal the employees' perception of job satisfaction factors and turnover intention. The mean of each variable was calculated and classified into five intervals using the method that was employed by Sudjana [15]. One hundred respondents were classified into five intervals in each variable. The following is the analysis result:

Table 3. Descriptive analysis result for variable $\mathrm{X}$

\begin{tabular}{crrrrrrl}
\hline \multirow{2}{*}{ Variable } & \multicolumn{4}{c}{ Respondents } & \multicolumn{2}{l}{ Average } & \multirow{2}{*}{ Interval } \\
& VDS & \multicolumn{1}{c}{ DS } & A & S & VS & Score & \\
\hline Work Itself (X1) & - & 2 & 25 & 55 & 18 & 3.76 & Satisfied \\
Salary (X2) & - & 35 & 33 & 27 & 5 & 2.28 & Dissatisfied \\
Promotion (X3) & 4 & 15 & 49 & 28 & 4 & 3.13 & Average \\
Superior (X4) & 3 & 11 & 25 & 52 & 9 & 3.45 & Satisfied \\
Colleagues (X5) & 1 & 0 & 10 & 57 & 32 & 4.01 & Satisfied \\
\hline
\end{tabular}

Explanation:

VDS : Very dissatisfied

DS : Dissatisfied 


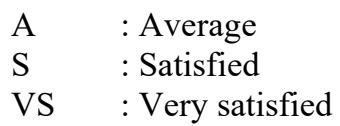

It can be inferred in the table above that for the "work itself" (X1), "supervision" (X4), and "colleagues" (X5) variables, the interval is "satisfied" with the average score of 3.76, 3.45, and 4.01 respectively. On the other hand, the interval for the "promotion" (X3) variable is "average" with an average score of 3.13 while "salary" (X2) is "dissatisfied" with the score of 2.28.

It can be inferred that $55 \%$ of the respondents were "satisfied" with variable X1, 35\% were "dissatisfied" with X2, 49\% were "average" with X3, 52\% were "satisfied" with X4, and $57 \%$ were "satisfied" with X5.

Table 4. Descriptive analysis result for variable $\mathrm{Y}$

\begin{tabular}{crcccccc}
\hline \multirow{2}{*}{ Variable } & \multicolumn{4}{c}{ Respondents } & \multicolumn{2}{c}{ Average } & \multirow{2}{*}{ Interval } \\
& SR & R & CT & T & ST & Score & \\
\hline Turnover Intention & 4 & 10 & 29 & 38 & 19 & 3.5 & High \\
\hline
\end{tabular}

It can be observed from the above table that the turnover intention variable (Y) has an average score of 3.5 , which is within the "high" interval, with $38 \%$ of the respondents selected the interval.

\subsection{Correlation result}

The following is the correlation result between variables using SPSS 23.0:

Table 5. Correlation variable result:

\begin{tabular}{crrrrrr}
\hline Variable & \multicolumn{1}{c}{ X1 } & \multicolumn{1}{c}{ X2 } & X3 & X4 & X5 & Y \\
\hline X1 & 1 & & & & & \\
X2 & 0.311 & 1 & & & & \\
X3 & 0.532 & 0.467 & 1 & & & \\
X4 & 0.486 & 0,371 & 0.699 & 1 & & \\
X5 & 0.534 & 0.124 & 0.400 & 0.495 & 1 & \\
Y & -0.309 & -0.436 & -0.467 & -0.405 & -0.188 & 1 \\
\hline
\end{tabular}

Based on the correlation analysis above, it could be seen that the "work itself" (X1) variable has the highest correlation with the "colleagues" (X5) variable with a score of 0.534 and it has the lowest correlation with "turnover intention" (Y) variable with a score of 0.309. On the other hand, the "salary" (X2) variable has the highest correlation with the "promotion" (X3) variable 
with a score of 0.467 and has the lowest correlation with the "colleagues" (X5) variable with a score of 0.124 . Meanwhile, for "promotion" (X3) variable has the highest correlation with the "supervision" (X4) variable with a score of 0.699 and has the lowest correlation with the "colleagues" (X5) variable with a score of 0.400 . For the "supervision" (X4) variable, it has the highest correlation with the "promotion" (X3) variable with a score of 0.699 and has the lowest correction with "salary" (X2) with a score of 0.371 . In addition, the "colleagues" (X5) variable has the highest correlation with the "work itself" (X1) variable and has the lowest correlation with the "salary" (X2) variable with a score of 0.124 .

\subsection{Multiple regression analysis}

The following is the results of multiple regression analysis between variables using SPSS 23.0:

Table 6. Multiple Linear Regression

\begin{tabular}{lrrrr}
\hline \multicolumn{1}{c}{ (Intercept) } & Estimate & Std. Error & \multicolumn{1}{c}{ t value } & \multicolumn{1}{c}{$\operatorname{Pr}(>|\mathrm{t}|)$} \\
& 33.57 & 3.583 & 9.369 & $4.041 \mathrm{e} 14-$ \\
(Intercept) & & & & 15 \\
\hline Work Itself (X1) & -0.1215 & 0.2518 & -0.4825 & 0.6305 \\
Salary (X2) & -0.5625 & 0.213 & -2.64 & 0.009695 \\
Promotion (X3) & -0.555 & 0.3129 & -1.774 & 0.07933 \\
Superior (X4) & -0.218 & 0.2125 & -1.026 & 0.3074 \\
Colleagues (X5) & 0.08069 & 0.2551 & 0.3163 & 0.7525 \\
\hline
\end{tabular}

Multiple linear regression analysis results show that the "salary" variable is significant with an alpha of 5\%. Based on the result, variable selection using the Stepwise regression method was conducted to obtain the best multiple linear regression model.

Table 7. F test result

\begin{tabular}{lcclcc}
\hline Model & $\begin{array}{c}\text { Sum } \\
\text { Square }\end{array}$ & Df & Mean Square & F & Sig \\
\hline Regression & 688.503 & $\mathbf{2}$ & 344.252 & 18.615 & $1.473 \mathrm{E} \mathrm{14-}$ \\
Residual & 1775.335 & $\mathbf{9 6}$ & 18.493 & & 07 \\
Total & 2463.838 & $\mathbf{9 8}$ & & & \\
\hline
\end{tabular}

Based on the ANOVA table above, it can be observed that the p-value of the F-test is $1.473 \times 10-7<0.05$. Therefore, it can be concluded that Ho is 
rejected, which means that an independent variable influences BRI Syariah employees' turnover intention.

Table 8. T-test result

\begin{tabular}{ccccc}
\hline & Estimate & Std. Error & $\mathrm{t}$ value & $\operatorname{Pr}(>|\mathrm{t}|)$ \\
\hline (Intercept) & 32.48 & 1.996 & 16.28 & $1.726 \mathrm{e}-29$ \\
X2 & -0.594 & 0.208 & -2.856 & 0.005248 \\
X3 & -0.7933 & 0.2292 & -3.461 & 0.0008015 \\
\hline
\end{tabular}

Based on the table above, it is shown that the p-value of the "salary" variable is $(0.005248)<0.05$. Therefore, it can be concluded that Ho is rejected and employee satisfaction of the salary negatively influences BRI Syariah employees' turnover intention.

On the other hand, the p-value of the "promotion" variable is $(0.0008)<0.05$. Therefore, it can be summarized that Ho is rejected and employee satisfaction of the promotion opportunity aspect negatively influences BRI Syariah employees' turnover intention.

Based on the table, it can be seen that the "salary" and "promotion" variable can be included in the following equation:

$$
\mathrm{Y}=32.48-0.594 \mathrm{X} 2-0.7933 \mathrm{X} 3
$$

Based on the equation, it is obtained that the influence of the "salary" variable on the turnover invention is -0.594 . It means that if the "salary" variable is increased by 1 , the turnover intention will be decreased by 0.594 . On the other hand, the "promotion" variable influence on turnover intention is -0.793 . It implies that if the promotion opportunity is increased, the turnover intention will be decreased by 0.793 .

Table 9. Coefficient of the determination result

\begin{tabular}{llll}
\hline Observations & $\begin{array}{l}\text { Residual } \\
\text { Std. Error }\end{array}$ & R Square & $\begin{array}{l}\text { Adjust R } \\
\text { Square }\end{array}$ \\
\hline 100 & 4.28 & 0.279 & 0.2641 \\
\hline
\end{tabular}

The obtained R2 score was 0.279 , which implies that $27.9 \%$ of turnover intention can be explained by "salary" and "promotion" variables while the rest can be explained by other variables outside the model. 
"Salary" and "promotion" variables are compensation. In this case, compensation is defined by Luturlean [16] as a payment given by an organization in financial, nonfinancial, or other forms for an individual who has performed their duty and has contributed to the organization. A more detailed explanation was given by Milkovich et al. [17] who explained that there are two types of compensation, which are total compensation and relational returns. Total compensation includes financial and all the benefits received by employees (basic salary, cost of living, incentives, insurance, bonus for positive performance). On the other hand, relational returns include a reward for achievement, praise, career development, challenge, and job security. Based on the previous description, it can be concluded that salary and promotion opportunities are forms of compensation. Based on Luturlean [16] study, a significant negative relationship between compensation and turnover intention exists. This finding is supported by Parashakti et al. [18] and Lauren [19] who found a negative relationship between compensation and employee turnover intention. It was found that higher compensation given to employees will decrease employee turnover intention.

Variable indicator of $\mathrm{X} 1$, which is the lowest, is related to the responsibility given by the superior in accordance with the employee capability and desire. The low indicator score could indirectly hinder employee's performance. This finding is supported by Muizu, Kaltum, and Sule [20] who found significant and positive influences between leadership and employees' performance. Based on the finding, it is suggested that BRI Syariah management could organize the capability of each employee and the work type assigned to them.

It was also found that the "salary" (X2) variable, which is related to wage policy and company compensation compared to other similar companies, has the lowest score. Salary is one of the compensations given by a company. Luturlean [16] describes compensation as a payment given by an organization in financial, nonfinancial, or other forms for an individual who has performed their duty and has contributed to the organization. If a company has relatively low compensation compared to other similar companies, it certainly would affect employees' work performance. Therefore, it is suggested that management should develop a new standard regarding the amount of salary or create various compensation packages to decrease employees' turnover intention. This finding is similar to Luturlean [16] who found that a significant negative relationship between compensation and turnover intention. 
Variable X3 shows that the lowest variable indicator is related to the issue of promotion opportunity provided by the company. Transparent and objective promotion processes could be observed by discipline, work performance, competence, loyalty, and educational compatibility [21]. Sari [22] found that there was a significant negative relationship between promotion and turnover intention.

Descriptive analysis of the $\mathrm{X} 4$ variable shows the lowest indicator score is related to the appreciation from superior for employees' contribution. Although the indicator is the lowest, it is still included in the "average" category. Appreciation and recognition from the superior contribution are related to the leadership style of the superior. It was found that leadership style perception has a significant and positive influence on employees' job satisfaction [23].

The high satisfaction level for the X5 variable indicates that most of BRI Syariah employees were satisfied with their colleagues. Of course, this aspect will make the employees contented and comfortable with their job and it is hoped that it could increase their job satisfaction. This finding is supported by Luthans [24] who explained that a good team could make a job more enjoyable. Other studies also describe that communication experience with colleagues will significantly influence work performance so that employees or colleagues could contribute to the quality and the quality of their job [25].

For variable $\mathrm{Y}$, it was shown that the average score can be included in the high category. The highest indicator is related to employees' desire to quit from the company if they have a better opportunity in other companies. On the other hand, the lowest indicator is related to leaving work for one year. Based on the finding, it can be observed that most of the BRI Syariah employees wished to find better opportunities in other companies, but it had not been planned within the next year. If it is not handled well, this issue could be disadvantageous for the company where it has many employees with low organizational commitment. This finding is also discussed by Ali et al. [26] who revealed a positive correlation between job satisfaction and organizational commitment. The study also found a significant and negative correlation between job satisfaction and turnover intention.

Based on the result, it can be concluded that job satisfaction simultaneously or partially influences the turnover intention of BRI Syariah employees. In addition, based on multiple linear regression analysis, it was revealed that the 
"salary" variable has a significant influence of alpha 5\%. To discover the result, the Stepwise regression method was employed to conduct variable selection to obtain the best multiple linear regression model. In this case, two variables, "salary" (X2) and "promotion" (X3), were selected with the influence scores of (-0.594) and (-0.793) respectively. This finding supports the hypothesis stated that the "salary" (X2) variable significantly and negatively influences employees' turnover intention. It also supports the hypothesis stated that the "promotion" (X3) variable significantly and negatively influences employees' turnover intention. These findings are also supported by previous studies that revealed that job satisfaction significantly and negatively influenced employees' turnover intention. It means that employees' high job satisfaction will decrease their intention to quit their job [27-31].

\section{Conclusions}

Job satisfaction simultaneously influences employees' turnover intention with a p-value of test score $(1.473 \times 10-7<0.05)$. It implies that there is one independent variable minimum that influences BRI Syariah employees' turnover intention. Partially, each of the job satisfaction factors of salary and promotion influences employees' turnover intention with scores of -0.594 and -0.793 respectively.

This study found that the job satisfaction of BRI Syariah employees is simultaneously categorized as "average" while partially, for the "work itself" variable, is categorized as Satisfied. On the other hand, the "salary' variable is categorized as Dissatisfied and the "promotion" variable is categorized as Average. Meanwhile, the "supervision" variable is categorized as Satisfied and "colleagues" as very satisfied. Furthermore, it was found that job satisfaction factors of salary and promotion opportunity have a negative and significant influence, simultaneously or partially, on turnover intention. In this case, it is suggested that BRI Syariah management to evaluate the standard of salary periodically and has to be more transparent in the promotion process.

\section{References}

[1] Hariandja MTE. Human Resource Management. Jakarta: Grasindo; 2002. 
[2] Pitaloka E. Dampak Modal Intelektual Terhadap Kinerja Bank Umum Nasional Periode 2010-2015. J Inspirasi Bisnis Dan Manaj 2017. https://doi.org/10.33603/jibm.v1i2.538.

[3] Rismayanti RD, Musadieq MA, Aini EK. Pengaruh Kepuasan Kerja terhadap Turnover Intention serta Dampaknya pada Kinerja Karyawan (Studi pada Karyawan Tetap Pg Kebon Agung Malang). J Adm Bisnis 2018;61:127-36.

[4] Bafadal I. Manajemen Peningkatan Mutu Sekolah Dasar. Jakarta: Bumi Aksara; 2006.

[5] Siagian SP. Manajemen Sumber Daya Manusia. Bandung: Bumi Aksara; 2015.

[6] Handoko TH. Manajemen Personalia dan Sumberdaya Manusia. Yogyakarta: Penerbit BPF; 2011.

[7] Simmons CA, Weiss EL, Schwartz SL. Job satisfaction indicators for tenure and non-tenure track social work faculty: similar but not equal. Soc Work Educ 2020;00:1-20. https://doi.org/10.1080/02615479.2020.1808608.

[8] Widyadmono VM. Pengaruh Kepuasan Kerja Dan Komitmen Organisasi Terhadap Turnover Intention (Studi pada Accounting Staff Perusahaan Swasta di DIY). J Manaj Indones 2015;15:157-68.

[9] Faslah R. Hubungan Antara Keterlibatan Kerja Dengan Turnover Intention Pada Karyawan PT. Garda Trimitra Utama, Jakarta. Econosains J Online Ekon Dan Pendidik 2010;8:146-51. https://doi.org/10.21009/econosains.0082.06.

[10] L. E. Nurmalasari. The Effect of Job Satisfaction on the Desire to Change Jobs with Organizational Commitment as an Intervening Variable. J Manaj Indones 2017;15:6-16.

[11] Halimah T, Fathoni A, Minarsih M. Pengaruh Job Insecurity, Kepuasan Kerja dan Lingkungan Kerja terhadap Turnover Intention Pramuniaga di Galael Supermarket (Studi Kasus pada Galael Superindo Kota Semarang). J Manage 2016. 
[12] Nasution (Muhammad). PENGARUH STRES KERJA, KEPUASAN KERJA DAN KOMITMEN ORGANISASI TERHADAP TURNOVER INTENTION MEDICAL REPRESENTATIVE. Mix J Ilm Manaj 2017. https://doi.org/10.22441/jurnal_mix.

[13] AlBattat AR, Som APM, Helalat AS. Overcoming Staff Turnover in the Hospitality Industry using Mobley's Model. Int J Learn Dev 2013. https://doi.org/10.5296/ijld.v3i6.4844.

[14] Sugiyono. Statistics for Research. Bandung: Alfabeta; 2013.

[15] Sudjana. Metode Statistika. Bandung: Tarsito; 2013.

[16] Luturlean BS. Kompensasi Sebagai Faktor Yang Mempengaruhi Tingkat Turnover Intention Karyawan Pada Kantor Badan Pengawas Pemilu. Bus J 2017;4.

[17] Milkovich G, Newman J, Gerhart B. Compensation. 11th ed. New York: MacGraw Hill; 2013.

[18] Parashakti RD, Nashar M, Usliawati D. The Effect of Compensation and Organization Commitment towards Turnover Intention. Case Study in ILC (International Language Center) Jakarta, 2017. https://doi.org/10.2991/icoi-17.2017.19.

[19] Lauren J. Pengaruh Kompensasi Dan Komitmen Organisasional Terhadap Turnover Intention Dengan Kepuasan Kerja Sebagai Variabel Mediasi Pada Karyawan. Agora 2017;5:56858.

[20] Muizu WOZ, Kaltum U, Sule ET. Pengaruh Kepemimpinan terhadap Kinerja Karyawan. J Pendidik Kewirausahaan Indones 2019;2:70-8.

[21] Hasibuan MSP. Manajemen Sumber Daya Manusia. Ed Revisi Jakarta Bumi Aksara 2011.

[22] Sari E. Pengaruh Kepuasan Kerja, Komitmen Dan Promosi Jabatan Terhadap Turnover Intention Pada Karyawan Pt. Orindo Alam Ayu Cabang Pekanbaru. Jom Fekon 2015;2:1-15.

[23] Tondok M, Andarika R. Hubungan antara Persepsi Gaya Kepemimpinan Transformasional dan Transaksional dengan Kepuasan 
Kerja Karyawan. Psyche (Stuttg) 2004;1:35-48.

[24] Luthans F. The need for and meaning of positive organizational behavior. J Organ Behav 2002. https://doi.org/10.1002/job.165.

[25] Shockley-Zalabak PS. Fundamentals of Organizational Communication. 9th ed. Colorado Springs: Pearson; 2015.

[26] Ali A, ZhongBin L, JianPing H, Ali Z, Sultan U. Examining the Relationships among Job Satisfaction, Organizational Commitment, and Turnover Intentions in Manufacturing Sector of Pakistan. Int J Acad Res Bus Soc Sci 2018. https://doi.org/10.6007/ijarbss/v8-i8/4428.

[27] Amri U, M A, Riyanto S. Pengaruh Kepuasan Kerja, Stres Kerja, dan Komitmen Organisasi terhadap Turnover Intention pada Head Office PT. Thamrin Brothers Palembang. J Kompetitif 2017;6:109-28.

[28] Firdaus A. FAKTOR-FAKTOR YANG MEMPENGARUHI TURNOVER INTENTION (Studi Pada Karyawan Perusahaan Jasa Multi Finance Di Kota Jambi). Ekon J Econ Bus 2017;1:1. https://doi.org/10.33087/ekonomis.v1i1.2.

[29] Putra; IGAGEM, Wibawa IMA. Pengaruh Kepuasan Kerja Terhadap Turnover Intention Dengan Komitmen Organisasi Sebagai Variabel Intervening Pada PT. Autobagus Rent Car Bali. E-Jurnal Manaj Unud 2015 .

[30] Eddy M.Sutanto, Carin Gunawan. Kepuasan Kerja, Komitmen Organisasional dan Turnover Intentions. Mitra Ekon Dan Manaj Bisnis 2013.

[31] Waspodo AA, Handayani NC, Paramita W. Pengaruh Kepuasan Kerja dan Stres Kerja terhadap Turnover Intention pada Karyawan PT. Unitex di Bogor. J Ris Manaj Sains Indones 2013. 